\title{
Soil Biology in the Ecuadorian Amazon
}

Created by: Thony Huera-lucero

Version received: 13 April 2020

check for

updates

For many decades the Ecuadorian Amazon has been used as source of resources for cities both at national and international level. These facts had important consequences and environmental impacts, affecting from the smallest living organisms of the soil to the indigenous communities and peoples that inhabit the Amazon rainforest, as well as the flora and fauna biodiversity. With the change in land use, the Amazonian territory has been progressively affected and it is gradually decreasing, leaving behind poor soils. Production conditions result modified by the implementation of large monocultures and livestock systems, a situation that directly affects soil and soil fauna. For this reason, we considered interesting to study, understand and compare the behavior of building organisms in natural and intervened areas, through sampling, inventories and laboratory analysis with the aim of developing and implementing production systems (chakras, agroforestry or silvopastoral systems), which benefit both the small producer and the ecosystem and life that inhabits it. Since there are no easily available compiled papers regarding the "Soil Biology in the Ecuadorian Amazon" in this work we collect information that allows us to offer a framework on the topics of changes in land use, typology of Amazonian soils and its main inhabitats organisms. All these date let to be considered as evidences of the degree of the health/disturbance of the corresponding soils.

\section{Biological Composition of Soils}

Soil is a dynamic and non-renewable live system whose condition and operation are crucial for food production and the preservation of environmental quality, and it is a key element to assess sustainability [1][2][3]. From the biological perspective, soil is a habitat where a large number of organisms reside, grouping in communities of fauna, bacteria, fungi, and algae, which interact with each other, performing important functions ${ }^{[4]}$. The fauna of the soil includes a variety of organisms of different species and sizes - the most diverse group being arthropods [5]. Depending on their diameter or length, they are usually classified as macrofauna, > $2 \mathrm{~mm}$; mesofauna, 0.1-2 mm; and microfauna, < 0.1 $\mathrm{mm}$ [4][5]6]7]. The invertebrates that make up the macrofauna participate as engineers in the formation of the different properties of the soil, in the crushing of plant matter, and some as predators [8]. The abundance, composition, and diversity vary from one land use to another [6]. They depend on soil management $[9]$. The organisms that make up the mesofauna are called microengineers. They improve the physical properties of the soil and break down organic matter (OM) on a small scale ${ }^{[10}$. They participate in the formation of edaphic microstructures as catalysts of microbial activity [7]. Invertebrates are the most abundant component of microfauna, with a high species richness. They are considered the most important predators of bacteria and fungi 4$][10]$.

All of them constitute the soil biota that is summarized in Table 1, which shows a classification according to the size of the main groups and the main functions that they are known to carry out in the soil.

Table 1. Organisms that constitute the soil biota and their main functions. Source: own elaboration based on[4][5][7].

\section{Living Organisms that Make up the Soil Biota}

Group

Organism

Earthworms

\section{Function}

They form a network of tunnels, mixing and digging the soil, producing excreta below and above the ground, modifying the water and chemical properties [4]. They transform the physical properties of the soil, benefiting the formation of aggregates, the movement and retention of water, as well as the gas exchange [8]. They act as ecosystem engineers in pore formation, water infiltration and OM humification and mineralization [6][10]. 
They participate in litter fractionation and in $\mathrm{OM}$ decomposition and mineralization Beetles processes ${ }^{[6]}$. The conservation of the coleoptera family can be a support for possible evaluations of the environmental quality [11].

Their mounds are rich in nutrients such as $\mathrm{N}, \mathrm{P}, \mathrm{K}, \mathrm{Ca}, \mathrm{Mg}$, and $\mathrm{Fe}$, favoring the proliferation of microflora and micromesofauna ${ }^{[12]}$. They affect the soil structure,

Ants

\section{Macrofauna}

$>2 \mathrm{~mm}$

Termites

Snails and slugs

Centipedes

and

Millipedes

Enquitraeid worms

Collembola

Mites

\section{Mesofauna}

1-2 $\mathrm{mm}$ mixing the horizons of the profile and recycling part of the elements that leach from the surface ${ }^{[13]}$. They modify the physical and chemical properties of the soil $[10]$, and contribute to the formation of aggregates, water filtration, and aeration ${ }^{[8]}$.

They contribute to bioturbation processes ${ }^{[4]}$, and intervene in the crushing of plant remains and in the decomposition of woody material [6].

They participate in litter fractionation and in $\mathrm{OM}$ decomposition and mineralization processes ${ }^{[6]}$, and the fragmentation of leaf litter, when they mobilize they secrete mucus, increasing area for microflora activity 4$][8]$. Their mucus helps aggregate formation, improving soil structure and properties $[10]$.

They live among the leaf litter or under the bark of trees and rocks, they play an important role as predators, and others participate in leaf litter fragmentation, speeding up the OM decomposition process $[8][10]$.

They participate in leaf litter maceration and plant remains, facilitating the transport of excavators, and they can also act as predators $[10]$.

They are decisive in the recycling of organic waste, dividing and crushing them, their excreta benefits the roots by the continuous release of nutrients. They participate as predators of nematodes and fungi [7]. They are considered a decisive element in the recycling of organic remains, and contribute to the structure of the soil [10].

Their role is to fragment leaves and dead wood, disperse microbial and fungal spores in the soil. Some species are predators of other microarthropods, nematodes, and mites [10]. Moreover, they contribute to the soil stability and fertility ${ }^{[7]}$, and in OM decomposition ${ }^{[14]}$.

They are concentrated in the roots, serve as food for plants, do not participate in OM decomposition [10], reflect the OM availability in different ecosystems, are the link in the food chain between microorganisms and complex organisms [7. Some can resist soil disturbances and chemical pollutants ${ }^{[15]}$, others are parasites. There are mycophagus, bacteriophages participate in the regulation of available nitrogen and phosphorus and influence the Rhizobium nodulation [10][14]. They are important agents of the nutrient cycle and regulators of soil fertility, and they work as biological control agents [15][16]. 
Protura, diplura, and pauropoda

\section{Microfauna $<2 \mathrm{~mm}$}

Fungi

Algae

\section{Bacteria}

They inhabit deep strata, under trunks or stones, they are detritivorous and depend on moderate and constant humidity, they consume microorganisms and fungal hyphae, which is why they are considered to be involved in decomposition, some of their representatives are predators and phytophagous [7][10].

They are considered the most important predators of bacteria and fungi. Moreover, they regulate microbial communities, and as pathogenic insects, represent an important biological control [4][10].

They are involved in processes of decomposition, mineralization, and cycling of nutrients [2][17]. By forming symbiotic associations, they increase the efficiency of plants to absorb nutrients [4], increase soil aggregation and participate in the carbon cycle [17], and allow plants to survive and efficiently absorb phosphorus from the soil ${ }^{[18]}$. They improve the soil health and plant species growth, provide greater absorption of nutrients, uptake of immobile ions, tolerance to toxic metals, root pathogens, and unfavorable conditions for plants in tropical ecosystems [2][10][19].

They are photosynthesizing organisms involved in primary production, organic carbon $(\mathrm{OC})$ compounds, and soil structure [10], and are colonizers. In association with fungi, they form lichens and contribute to soil formation, degrading minerals or rocks by excreting organic acids [20]. From the production of carbohydrates, they form soil aggregates and stop their erosion [21]. Given the variable and morphologically similar nature of the majority, today, they are identified using molecular techniques [22][23][24].

They rarely contribute to biological activity. They can be considered bags full of enzymes ${ }^{[10]}$. In the soil they are very numerous and genetically different. Some degrade chemical compounds and others form nodules in the roots of legumes, with the function of fixing atmospheric nitrogen through heterocysts. Cases such as Pseudomonas can be pathogenic [10][25]. There are cyanobacteria (photosynthesizers and autotrophs) [26]; Actinobacteria are colonies similar to fungal mycelia, like Actinomycetes that degrade $\mathrm{OM}$ to form humus and participate in the mineralization process, others can fix $\mathrm{N}$ or regulate the composition of the microbial community in the soil. They secrete enzymes that serve for the biological control of nematodes, insects, and other soil organisms. Their number on agricultural land is high [2].

\subsection{Contextualization of Ecuadorian Amazon Soil Types, Management, Uses, and Problems}

The Ecuadorian Amazon constitutes 45\% of the National territory, occupying 115,613 km, extending from the Andean mountain foothills, with the appearance of transitional forests at 1300 m.a.s.l., to the east of the Amazonian plain, forming less than $2 \%$ of the Amazon River basin. The average rainfall fluctuates between 2000 and 5000 mm annually, with a temperature of $24{ }^{\circ} \mathrm{C}$ during the year, which constitutes a warm damp climate [27][28].

The Ecuadorian Amazon has been referred to as "the most important source of fresh water and biodiversity" for its global climate regulatory function as a greenhouse gas sink [29]. It is made up of six provinces: Sucumbíos, Orellana, Napo, Pastaza, Morona Santiago, and Zamora Chinchipe (Figure 1), which have a variety of soil types, from the Andes to soil derived from volcanic ash with specific characteristics [27][30][31]. Due to the geological and influence of 
meteorological factors, poorly developed soils appear with acidic $\mathrm{pH}$, that are susceptible to erosion due to high rainfall, low fertility and nutrient availability, the presence of toxic aluminum for plants, and high moisture retention [27][31][32].

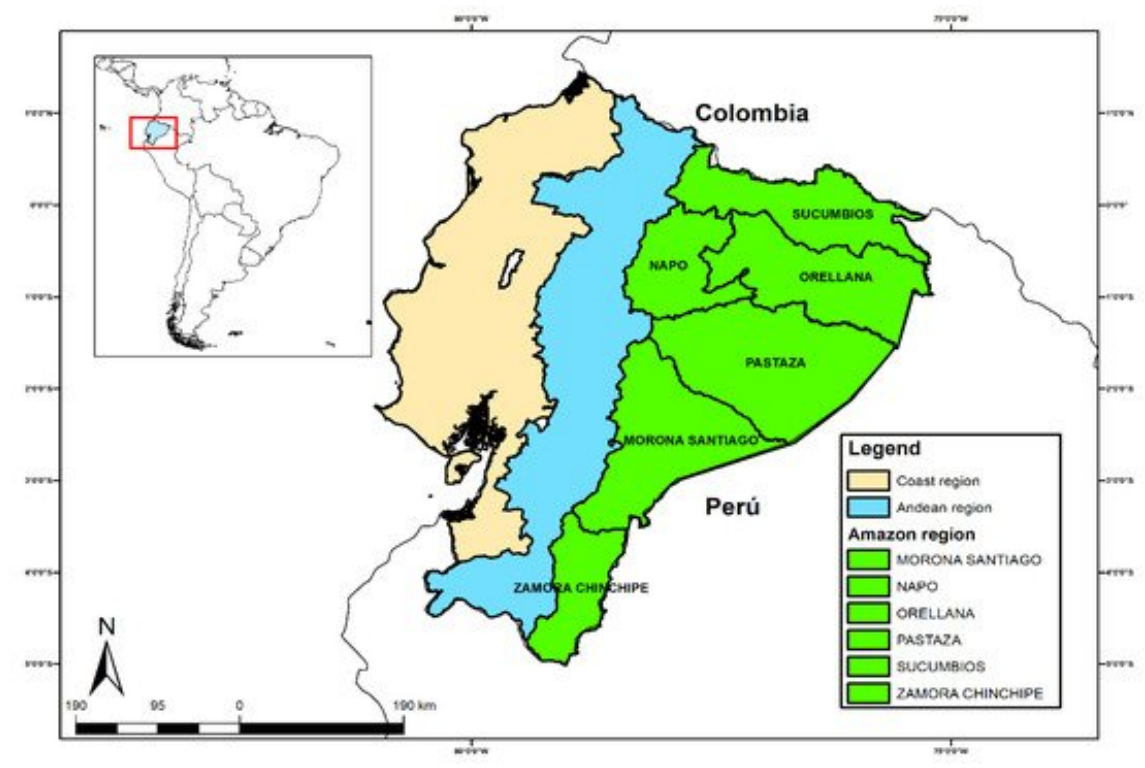

Figure 1. Political map of the Amazon region of Ecuador.

According to the American Soil Taxonomy (USDA) system, the soils present in the Ecuadorian Amazon belong to the typological units that are collected in Table 2, prepared from information compiled by the SIGAGRO (Geographic and Agricultural Information System) of the Ministry of Agriculture Livestock Aquaculture and Fisheries of Ecuador [31][32][33]. The most representative soils of the Amazon territory are those of order inceptisol, entisol, histosol, and mollisol [34][35].

Table 2. Taxonomic classification of soils in the Ecuadorian Amazon, based on[31][32][33].

\section{Taxonomic Description of the Soils of the Ecuadorian Amazon}

\section{Order}

Alfisol: Mineral soils developed in stable reliefs of erosive tectonic origin, with clays in the surface horizon, and with more than $35 \%$ base saturation; because of the natural reserve of nutrients, they are considered good for short-cycle farms and forages.

Entisol: Soils with the scarce formation of horizons, either due to susceptibility to erosion and flooding, or due to the short evolution time; of variable fertility, due to the original material dragged by alluviums or rivers; present agricultural vocation, but the excess of humidity is their main limitation.

Histosol: Organic soils that are formed when the OM exceeds its mineralization, that are without Indian origins, and are limited in swampy areas that are poorly drained under conditions of continuous saturation that prevents the circulation of oxygen. In this type of soil, sustainable use is limited to forested formations, grasslands, and in some cases, intensive crops. Their ecological importance is because they act as carbon sinks due to the speed of OM contributions they receive.
Suborder

Typic

Udifluvents

\section{Aquept}

Fibrist 
Inceptisol: Soils with a lack of edaphological maturity, whose genesis is of rapid formation. They occupy areas of irregular topography, with both humid and subhumid climates, and have variable chemical and physical properties, from acid to alkaline, sandy to clay. They have-more or less-a base saturation of $60 \%$, and have been used by the agricultural sector for key crops for the economy. They are represented by a forest cover, pastures, and representative crops.

Mollisol: Very fertile soils, with a surface horizon rich in OM and more than $50 \%$ of base saturation; occupy structural reliefs, with slight slopes towards the coast and sedimentary valleys of volcanic origin; develop in a variety of climatic regimes, mostly grassland vegetation, with high agricultural yield, sometimes the highest in the world.

Oxisol: Mineral soils with low fertility, from marginal slopes of the Real and Cutucú mountain range; occupy tropical areas that have gone through prolonged processes of weathering and washing due to heavy rainfall; have red, yellowish colors due to iron accumulation, oxides, and hydroxides of aluminum. Their main use is for livestock, followed by forest areas, but they are not suitable for agricultural activities.

Ultisol: Acidic soils, which are products of chemical weathering, from eastern and western Andean hills, present in any humidity regime, with a base saturation of less than $35 \%$ providing acidity. These soils are characteristic of humid forests that are part of conservation areas.

Due to the biological richness and endemism of the Ecuadorian Amazon, it is one of the largest ecological reserves, with a high potential to provide ecosystem services to local populations. Being subject to high rates of deforestation and changes in use affects the biodiversity, soil, and water, as basic components of an ecosystem, causing the decrease or loss of possible ecosystem goods and services [29][36].

In tropical regions, the change from forests to pastures and agricultural production, on the one hand, leads to losses in terms of fertility, quality, and biodiversity in the soils, and on the other hand, implies the addition of nutrients and amendments to meet the demand for crops; hence, to promote a change in the productive matrix with a sustainable vision, the best strategy is the implementation of agroforestry or silvopastoral systems [2][30][36][37]. This confirms that the Ecuadorian Amazon is not suitable for intensive agricultural activity, but for productive systems similar to the forest 31$]$. The most common systems are described below.

Silvopastoral systems: Due to the dependence of part of the Amazonian population on livestock activity, it has been necessary to generate production models similar to the forest (silvopastoral systems) [34]. This consists of combining the use of trees, pastures, and animals to increase production, which at the same time brings other benefits, such as wood, biodiversity conservation, carbon fixation, and the protection of water basins and soil [27]. These systems represent a sustainable alternative, which responds satisfactorily to the socio-economic reality of tropical countries, mainly with regard to food demand [38]. In the Ecuadorian Amazon, with colonization, the forests were intervened and used for timber resources, and the establishment of pastures and small orchards [37]. Livestock has turned soils into degraded lands, dependent on mechanization and agrochemicals [35]. Despite this problem, there is an interest in understanding the state of those soils, and implementing strategies or systems compatible with the environment, soil, edaphic life, and livestock farmers [3]. The adoption of silvopastoral systems has increased the biomass in the soil surface, the level of $\mathrm{OM}$ in the surface horizon, and thereby the availability and recycling of nutrients, hence improving the soil structural 
index [1]27][30]. On the other hand, the grass influences the system; for example, long-cycle gramalote grass Axonopus scoparius) does not affect the soil, but forms associations with short-cycle pastures, such as honey grass \$etaria plendida), Amazonian kikuyo (Brachiaria humidicola), dallis (Brachiaria decumbens), or elephant grass (Pennisetum purpureum), in which they can produce important erosion and soil degradation processes ${ }^{[1]}$.

Crops: In the Ecuadorian Amazon, many agricultural projects have been promoted with African palm, coffee, cacao, rice, and grassland, from which extensive (monoculture) crops have originated that involve the deforestation of largescale virgin forest. Projects that expanded the agricultural frontier for state support (credits) ${ }^{[34]}$. Incentives for planting African palm and palmito, mainly, have caused significant losses in biological biodiversity and vegetation, altering the multifunctionality that ecosystems play [7][34]. The management techniques used in monocultures affect the soil community and make them dependent on external inputs [7], without neglecting the deterioration and degradation of soils that are of little interest to large producers, whose only interest lies in the profitability and economic benefits that they can obtain.

On the other hand, there are polycultures or chakras, which have developed Amazonian populations for family subsistence. The chakras are implanted within the forests, occupying small areas, and include some natural plant species. In addition, they open a variety of crops, such as cassava, banana, Chinese potato, naranjilla, sugarcane, as well as fruit trees of chontaduro, guaba, papaya, and wild grapes, naturally [37], without neglecting the variety of medicinal plants. The ideology is to maintain a balance between the chakras and nature without altering the structure, the life that inhabits the area, or the soil.

Agroforestry systems: In Amazonian ecosystems, they fulfil important functions. These systems improve the relationships between the soil, water, and air components of the ecosystem [36],39]. When linking crops, such as cocoa or coffee, the damage caused to the soil is minimal. The constant addition of litter and root development that increase the soil's OM produces conditions similar to those of a natural forest [1][27]. The similarity of conditions of these systems with forests allows the development of processes, such as recycling, fixation, and mineralization of nutrients $[36$. They prevent the implantation of monocultures and the impacts of deforestation. At the same time, they generate other economic inputs for producers, such as wood production, firewood, wild fruits; together with environmental services, such as the reduction of greenhouse gases, carbon sequestration, and protection of natural resources (soil, air, water) [38]. They serve as habitats for plant and animal species, from microorganisms, vertebrates, and amphibians of the soil, to large mammals and birds [37][39].

In Ecuador and tropical regions in general, the conversion of forests to agricultural and livestock systems is the most important reason for land-use change [40]. These changes lead to the alteration and loss of biodiversity, and mainly to deterioration of the soil [27][31].

Forests: The Amazon is characterized by its lush vegetation, and for having soils with a superficial horizon rich in OM. These data led us to mistakenly think that they were fertile lands. After several investigations in deforested areas, it has been proven that Amazonian lands are not very fertile. They become impoverished quickly in the absence of organic remains provided by the vegetation cover [39]. In Amazonian soils, despite the low availability of nutrients, forests have adapted to weathering and washing conditions, capturing the nutrients generated by the decomposition of the OM directly with their surface roots [34].

In Ecuador, oil activity is indirectly responsible for the current state of Amazonian forests $4 \underline{41]}$. With the appearance of oil companies, agricultural and livestock activities have positioned themselves as being the main and majority use of the Amazon region [37][42]. Currently, institutions and research centers are developing projects aimed at the sustainable use of natural resources [39]. These projects are associated with environmentally friendly management systems and practices that benefit the Amazonian community. In the Ecuadorian Amazon, most forests that are not part of the National System of Protected Areas of Ecuador (SNAP) or some protective forest are degraded either by the selective extraction of species or because they are secondary forests [42].

\section{References}


1. Bravo, Carlos; Torres, Bolier; Alemán, Reinaldo; Marín, Haide; Durazno, Galo; Navarrete, Henrry; Gutiérrez, Eberto Tuniesky; Tapia, Aracely; Indicadores morfológicos y estructurales de calidad y potencial de erosión del suelo bajo diferentes usos de la tierra en la Amazonía ecuatoriana. Anales de Geografia de la Universidad Complutense 2017, 37, 247-264, 10.5209/AGUC.57725.

2. Pfenning, Ludwig H.; Abreu, Luas Magalhães. Manual de biología de suelos tropicales: Hongos del suelo saprófitos y patógenos de plantas; Instituto Nacional de Ecología: México, 2000; pp. 243-280.

3. Cherubin, Maurício R.; Karlen, Douglas L.; Franco, André L.C.; Cerri, Carlos E.P.; Tormena, Cássio A.; Cerri, Carlos C.; A Soil Management Assessment Framework (SMAF) evaluation of Brazilian sugarcane expansion on soil quality. Soil Science Society of America Journal 2016, 80, 215-226, 10.2136/sssaj2015.09.0328.

4. Moreira, Fatima; Huising, Jeroen E; Bignell, David E.. Manual de Biologia de suelos tropicales : muestreo y caracterizacion de la biodiversidad bajo suelo; Instituto Nacional de Ecologîa: México, 2012; pp. 300.

5. Moldenke, Andrew R.; Arthropods. Methods of soil analysis. Soil Science Society of America Journal 1994, $42,517$.

6. Cabrera, Grisel; La macrofauna edáfica como indicador biológico del estado de conservación/perturbación del suelo. Resultados obtenidos en Cuba. Pastos y Forrajes 2012, 35, 349-363.

7. Socarrás A.; Mesofauna edáfica: indicador biológico de la calidad del suelo. Mesofauna edáfica: indicador biológico de la calidad del suelo 2013, 36, 5-13.

8. Cabrera, Grisel; Robaina, Nayla; Ponce de Leon, D; Composicion funcional de la macrofauna edafica en cuatro usos de la tierra en las provincias de Artemisa y Mayabeque, Cuba. Pastos y Forrajes 2011, 34, 313-330.

9. Bonilla, Carmen; Gómez, Eyder; Sánchez, Marina. El suelo: los organismos que lo habitan; Universidad Nacional de Colombia: Palmira, Colombia, 2020; pp. 1-18.

10. Coyne, Mark. Microbiología del suelo: un enfoque exploratorio; Paraninfo: Madrid, 2000; pp. 416.

11. Chamorro, William R.; Gallo, Freddy O.; Delgado, Soraya; Enríquez, Sandra I.; Guasumba, Verónica; López-lborra, Germán; Los escarabajos estercoleros (Coleoptera: Scarabaeidae: Scarabaeinae) del Bosque Protector Oglán Alto, Pastaza, Ecuador. Biota Colombiana 2019, 20, 34-49, 10.21068/c2019.v20n01a03.

12. Jones, David T.; Eggleton, Paul; Sampling termite assemblages in tropical forests: Testing a rapid biodiversity assessment protocol. Journal of Applied Ecology 2000, 37, 191-203, 10.1046/j.1365-2664.2000.00464.x.

13. González, Grizelle; Zou, Xiaoming; Borges, Sonia; Earthworm abundance and species composition in abandoned tropical croplands: comparisons of tree plantations and secondary forests. Pedobiología 1996, 40, 385-391.

14. García-Álvarez, A.; Bello, A. Diversidad de los organismos de suelo y transformaciones de la materiaorgánica. In Proceedings of the International Conference Soil Compost Eco-Biology, León, España, 15-17September 2004; pp. 211-212.

15. Cares, Juvenil E.; Huang, Shiou P.; Nematodos del Suelo. Manual de biologia de suelos tropicales 2012, 5, 163-176.

16. Traunspurger, Walter; Reiff, Nicola; Krashevska, Valentyna; Majdi, Nabil; Scheu, Stefan; Diversity and distribution of soil microinvertebrates across an altitudinal gradient in a tropical montane rainforest of Ecuador, with focus on free- living nematodes. Pedobiología-Journal of Soil Ecology 2017, 62, 28-35, 10.1016/j.pedobi.2017.04.003.

17. Ruiz, Pedro; Rojas, Krystel; Sieverding, Ewald; La distribución geográfica de los hongos de micorriza arbuscular: una prioridad de investigación en la Amazonía peruana. Espacio y Desarrollo 2011, 23, 47-63.

18. Alemán, Reinaldo; Reyes, Hector; Bravo, Carlos. Libro de Memorias: Simposio internacional sobre Manejo sostenible de tierras y seguridad alimentaria - Ecuador 2017; Alemán-Pérez, Reinaldo; Reyes-Morán, Héctor; Bravo-Medina, Carlos, Eds.; Universidad Estatal Amazónica: Puyo, Pastaza-Ecuador, 2017; pp. 279.

19. Bagyaraj, Joseph D.; Stürmer, Sidney L.. Manual de Biología de Suelos Tropicales: Hongos micorrizógenos arbusculares (HMA); Instituto Nacional de Ecología. DF: México, 2012; pp. 217-242.

20. Carey, Joanna C.; Fulweiler, Robinson W.; The Terrestrial Silica Pump. PLoS ONE 2012, 7, 52, 10.1371/journal.pone.0052932.

21. Stanek-Tarkowska, J; Noga, T; Diversity of diatoms (Bacillariophyceae) in the soil. Inżynieria Ekologiczna 2012, 30, 287-296.

22. Hallmann, C. Biodiversity of Terrestrial Algal Communities from Soil and Air-Exposed Substrates Using aMolecular Approach. Ph.D. Thesis, Georg-August-University School of Science, Gottinghem, Germany, 2015

23. Maistro, Silvia; Broady, Paul; Andreoli, Carlo; Negrisolo, Enrico. Handbook of the Protists: Xanthophyceae; Springer International Publishing: Cham, 2017; pp. 407-434.

24. Bérard, A.; Dorigo, U.; Humbert, J. F.; Martin-Laurent, F.; Microalgae community structure analysis based on $18 \mathrm{~S}$ rDNA amplification from DNA extracted directly from soil as a potential soil bioindicator. Agronomie 2005, 25, 285-291, 10.1051/agro:2005004.

25. Moreira, Fátima. Manual de biología de suelos tropicales: Muestro y caracterización de la biodiversidad bajo suelo: Bacterias formadoras de nódulos en leguminosas; Instituto Nacional de Ecologîa: México, 2012; pp. 177-216.

26. Corrales Morales, Mariela; Villalobos, Karolina; Rodríguez Rodríguez, Abad; Muñoz Simón, Nelson; Umaña-Castro, Rodolfo; Identificación y caracterización molecular de cianobacterias tropicales de los géneros Nostoc, Calothrix, Tolypothrix y Scytonema (Nostocales: Nostocaceae), con posible potencial biotecnológico. UNED Research Journal 2017, 9, 280-288, 10.22458/urj.v9i2.1710.

27. Bravo, Carlos; Benítez, Diócledes; Vargas Burgos, Julio; Alemán, Reinaldo; Torres, Bolier; Marín, Haideé; Caracterización socioambiental de unidades de producción agropecuaria en la Región Amazónica Ecuatoriana: Caso Pastaza y Napo. Revista Amazónica Ciencia y Tecnología 2015, 4, 3-31.

28. Bravo-Velásquez, Elizabeth. Apuntes sobre la biodiversidad del Ecuador; Abya-Yala, Editorial Universitaria: Cuenca-Ecuador, 2013; pp. 13.

29. López, V.; Espíndola, F.; Callles, J.; Ulloa, J. Amazonía Ecuatoriana Bajo Presión; Eco Ciencia: Quito, Ecuador,2013 
30. Izquierdo, I.; Caravaca, F.; Alguacil, M. M.; Roldan, A.; Changes in Physical and Biological Soil Quality Indicators in a Tropical Crop System (Havana, Cuba) in Response to Different Agroecological Management Practices. Environmental Management 2003, 32, 639645, 10.1007/s00267-003-3034-2.

31. Diaz, Alejandra. Agroforestería Sostenible en la Amazonía Ecuatoriana, N² 2, Fragilidad de los suelos en la Amazonía ecuatoriana y potenciales alternativas agroforestales para el manejo sostenible: Caracterización de los suelos de la Amazonía ecuatoriana. ; INIAPEstación Experimental Central Amazónica: Joya de los Sachas, Ecuador, 2018; pp. 33-40.

32. Rodríguez-Achung, Fernando; Bendayán-Acosta, León; Rojas-Rodríguez, Carlos; Calle-Barco, Carlos; Los suelos de la región del Amazonas segun unidades fisiográficas. Folia Amazónica 2006, 3, 7-20, 10.24841/fa.v3i1-2.198.

33. MAG, (Ministerio de Agricultura y Ganadería) Memoria Explicativa del Mapa de Órdenes de Suelos delEcuador. Available online: http://metadatos.sigtierras.gob.ec/pdf/MEMORIA_MAPA_DE_ORDENES_DE_SUELOS_MAG_SIGTIERRAS.pdf (accessed on 16 February 2020).

34. Vargas, Yadira; Nicolalde, José; Calero, Andrés; Vizuete, Omar. Agroforestería Sostenible en la Amazonía Ecuatoriana, N², Fragilidad de los suelos en la Amazonía ecuatoriana y potenciales alternativas agroforestales para el manejo sostenible: ¿Por qué son frágiles los suelos de la Amazonía ecuatoriana?; INIAP-Estación Experimental Central Amazónica: Joya de los Sachas, Ecuador, 2018; pp. 61-68.

35. Nieto, Carlos; Caicedo, Carlos; Análisis reflexivo sobre el desarrollo agropecuario sostenible en la Amazonía Ecuatoriana, INIAP EECA.. Iniap 2012, 24-50, 102.

36. Bravo, Carlos; Ramírez, Alina; Marín, Haideé; Torres, Bolier; Alemán, Reinaldo; Torres, Roldan; Navarrete, Henry; Changoluisa, Daysi; Factores asociados a la fertilidad del suelo en diferentes usos de la tierra de la Región Amazónica Ecuatoriana. Revista Electronica de Veterinaria 2017, 18, 1-16.

37. Torres, B.; Starnfeld, F.; Vargas, J.C.; Ramm, G.; Chapalbay, R.; Rios, M.; Gómez, A.; Torricelli, Y.; Jurrius, I.;Tapia, A.; et al. Gobernanza Participativa en la Amazonía del Ecuador: Recursos Naturales y Desarrollo Sostenible;Manthra: Quito, Ecuador, 2014.

38. Vallejo Quintero, Victoria Eugenia; Importancia y utilidad de la evaluación de la calidad de suelos a través del componente microbiano: Experiencias en sistemas silvopastoriles. Colombia Forestal 2013, 16, 83-99, 10.14483/udistrital.jour.colomb.for.2013.1.a06.

39. Tapia-Báez, R.G. Diversidad de Escarabajos Copronecrófagos y Estado de Consevación de la Microcuenca del RíoPindo; Universisdad Tecnológica Equinoccial: Quito, Ecuador, 2015.

40. Bravo, Carlos; Torres, Bolier; Alemán, Reinaldo; Changoluisa, Daysi; Marín, Haideé; Reyes, Héctor; Navarrete, Henry; Soil structure and carbon sequestration as ecosystem services under different land uses in the Ecuadorian Amazon Region. MOL2NET 2017, 1-8, 3, 10.3390/mol2net-03-xxxx.

41. Palacios, W.; Malessa, U. Situación de las Comunidades Productoras Forestales de la Amazonía Ecuatoriana:Obstáculos y Oportunidades Para Comercializar Madera Legal; TRAFFIC, Oficina regional America del Sur: Quito,Ecuador, 2010.

42. Camacho, D. Cordero; Esquemas de pagos por servicios ambientales para la conservación de cuencas hidrográficas en el Ecuador. Investigación Agraria: Sistemas y Recursos Forestales 2008, 17, 54-66, 10.31819/9783954878284-001.

\section{Keywords}

Soil biology; Edaphic biota; Ecuadorian Amazon; Ecuador

(C) 2020 by the author(s). Distribute under aCreative Commans CC BY license 